\title{
Internalisasi Soft Skills dan Minat Kewirausahaan dalam Pembentukan Jiwa Kewirausahaan
}

\author{
Putri Yunita Aprillianita \\ e-mail: putriyunitaap01@upi.edu \\ Eeng Ahman \\ e-mail: eengahman@upi.edu \\ Kodri \\ e-mail:kodri_magisterekononi@upi.edu
}

(Program Studi Pendidikan Ekonomi, Sekolah Pascasarjana, Universitas Pendidikan Indonesia, Jawa Barat)

\begin{abstract}
ABSTRAK: Penelitian ini bertujuan untuk mengetahui dan menganalisis pengaruh internalisasi soft skills dan minat kewirausahaan dalam pembentukan jiwa kewirausahaan siswa di MAN Se-Kabupaten Kuningan. Metode yang digunakan dalam penelitian ini adalah metode survey eksplanatori dengan teknik pengumpulan data melalui penyebaran kuesioner kepada siswa MAN Se-Kabupaten Kuningan. Instrumen penelitian yang digunakan sudah di uji validitas dan reabilitas. Populasi penelitian ini adalah seluruh siswa MAN SeKabupaten Kuningan sebanyak 2.123 siswa sedangkan berdasarkan perhitungan Slovin diperoleh sampel sebanyak 355 siswa. Data yang telah terkumpul kemudian dianalisis menggunakan teknik analisis secra deskriptif dan regresi linier berganda. Hasil penelitian menunjukkan bahwa: 1) tingkat internalisasi soft skills, minat kewirausahaan dan jiwa kewirausahaan siswa berada pada kategori tinggi. 2) internalisasi soft skills berpengaruh terhadap pembentukan jiwa kewirausahaan. 3) minat kewirausahaan berpengaruh terhadap pembentukan jiwa kewirausahaan. 4) internaslisasi soft skills dan minat kewirausahaan berpengaruh terhadap pembentukan jiwa kewirausahaan. Temuan ini mengindikasikan bahwa untuk membentuk jiwa kewirausahaan, maka perlu adanya upaya peningkatan internalisasi soft skills dan minat kewirausahaan.
\end{abstract}

Kata kunci - Internalisasi softsSkill, minat kewirausahaan, jiwa Kewirausahaan.

ABSTRACT : This study aims to determine and analyze the effect of internalization of soft skills and entrepreneurial interest in the formation of the entrepreneurial spirit of students in MAN in Kuningan Regency. The method used in this study is an explanatory survey method with data collection techniques through distributing questionnaires to students of MAN in Kuningan Regency. The research instrument used has been tested for validity and reliability. The population of this research is all students of MAN in Kuningan Regency as many as 2,123 students, while based on Slovin calculation, the sample is 355 students. The collected data were then analyzed using descriptive analysis techniques and multiple linear regression. The results showed that: 1) the level of internalization of soft skills, entrepreneurial interest and entrepreneurial spirit of students were in the high category. 2) internalization of soft skills has an effect on the formation of an entrepreneurial spirit. 3) interest in entrepreneurship affects the formation of an entrepreneurial spirit. 4) internationalization of soft skills and entrepreneurial interest have an effect on the formation of an entrepreneurial spirit. These findings indicate that to form an entrepreneurial spirit, it is necessary to increase the internalization of soft skills and interest in entrepreneurship.

Keywords - Internalization of soft skills, entrepreneurship interests, entrepreneurial soul. 


\section{PENDAHULUAN}

Era globalisasi, persaingan mencari kerja semakin kompetitif sementara lapangan pekerjaan yang ditawarkan juga terbatas, menuntut siswa dan kaum muda harus lebih berpikir kreatif (Fletcher \& Nusbaum, 2010). Semangat entrepreneurship ini sudah menjadi tuntutan zaman, meski ada juga sebagian pihak yang menjadikan kewirausahaan ini sebagai trend saja (Buchholz \& Rosenthal, 2005). Majunya suatu negara dapat dilihat dari banyaknya wirausahawan di negara tersebut, semakin banyak jumlah wirausahawan semakin besar harapan masyarakat usia kerja dapat memperoleh pekerjaan sesuai dengan keahlian, sehingga dapat mengangkat derajat hidup masyarakat suatu negara, karena akan tercipta lapangan pekerjaan dan akan mengurangi tingkat pengangguran (Ghosh \& Cheruvalath, 2007).

Indonesia amat sangat membutuhkan banyak wirausaha baru terutama para generasi muda yang berwirausaha. Tingkat pengangguran, baik yang tidak berpendidikan maupun yang berpendidikan, serta sedikitnya lapangan kerja merupakan jawaban mengapa kita memerlukan adanya wirausaha baru (Bhasin \& Venkataramany, 2010). Dengan demikian, menjadi wirausaha pada saat ini sangatlah diperlukan, bukan hanya untuk kepentingan diri sendiri, tetapi yang paling utama adalah sebagai pengabdian kita kepada bangsa dan negara dengan menciptakan lapangan kerja untuk orang banyak (Kadiyono, 2014).

Wirausaha diyakini sebagai roda penggerak pertumbuhan ekonomi, serta wirausaha juga dianggap sebagai inovator dalam pengembangan ekonomi. Tingginya persentase jumlah wirausaha di suatu negara maka perekonomian negara tersebut akan tumbuh dengan baik (Nursiah, Kusnadi, \& Burhanuddin, 2017). Untuk menjadi seorang wirausaha tentu saja terlebih dahulu didalam jiwa orang tersebut terdapat jiwa wirausaha. Jiwa kewirausahaan adalah jiwa yang mampu menciptakan nilai tambah dari keterbatasan dalam upaya menciptakan nilai tambah, dengan menangkap peluang bisnis dan mengelola sumber daya untuk mewujudkannya (Ningrum, 2017). Jiwa kewirausahaan merupakan salah satu bekal untuk hidup dimasyarakat dengan baik. Jiwa adalah sesuatu yang abstrak, yang dipelajari hanya pernyataan-pernyataan yang tampak dengan tubuh, atau gejala-gejala yang tampak sebagai gerak-gerik sehingga jiwa merupakan roh, setiap manusia mempunyai sifat dan gejala abstrak terjadi dari perasaan, pikiran, angan-angan dan sebagainya (Fikroh, Lestari, \& Tuban, 2019).

Jika dikaitkan dengan jiwa kewirausahaan, maka internalisasi merujuk pada proses penanaman dan pengembangan jiwa kewirausahaan tertentu pada pribadi seseorang. Dengan demikian, internalisasi soft skills dapat dimaknai sebagai proses edukatif berupa penanaman dan pengembangan jiwa kewirausahaan yang berperan sebagai daya pendorong dan menjadi pedoman dalam menjalani kehidupan menuju kemandirian. Relevansi soft skills dengan kebutuhan dunia kerja yang diselenggarakan dan ketersediaan lulusan dengan keterserapan dunia kerja/usaha terhadap lulusan tersebut saat ini sangat tidak seimbang (Bygrave, 2010).

Sehingga, banyak siswa yang lulus dan bekerja tidak sesuai dengan bidang keahlian yang dimilikinya. Untuk memperoleh lulusan yang siap kerja, dunia usaha yang dikelola, menetapkan sistem seleksi dengan menggunakan tes spiritual quotient (SQ). Tes tersebut memenuhi kebutuhan IQ maupun EQ calon karawan, bahkan indikasinya cenderung baik dan peserta tes dapat bekerja sama. Jika seseorang mempunyai kedua kompetensi itu, silakan dengan terbuka merebut kesempatan yang sama tanpa diskriminasi untuk memperoleh pekerjaan dan perlakuan dalam bekerja (Priyono, 2017). 
Selain internalisasi soft skills, faktor lain yang dapat mempengaruhi pembentukan jiwa kewirausahaan seseorang adalah minat berwirausaha karena minat berwirausaha akan membuat seseorang cenderung terhadap suatu hal. Minat wirausaha adalah kemampuan untuk memberanikan diri dalam memenuhi kebutuhan hidup serta memecahkan permasalahan hidup, memajukan usaha atau menciptakan usaha baru dengan kekuatan yang ada pada diri sendiri. Hal yang paling utama yaitu sifat keberanian untuk menciptakan usaha baru (Kurniawan, Khafid, \& Pujiati, 2016). Minat berwirausaha merupakan perubahan sikap dan pandangan generasi muda calon intelektual bangsa kita dan perubahan sikap orang tua yang menyenangi dan mengizinkan putra-putrinya untuk terjun kebidang bisnis (Rosmiati, Junias, \& Munawar, 2015). Para remaja banyak mengatakan bahwa mereka sangat menyenangi kegiatan bisnis, karena pekerjaan bisnis cukup menjanjikan dimasa depan sehingga untuk mengantisipasi pekerjaan bisnis, mereka mempersiapkan bekal, berupa mental dan keterampilan menunjang. Minat wirausaha adalah gejala psikis untuk memusatkan perhatian dan berbuat sesuatu terhadap wirausaha itu dengan perasaan senang karena membawa manfaat bagi dirinya. Inti dari pendapat tersebut adalah pemusatan perhatian yang disertai rasa senang.

Penelitian mengenai internalisasi soft skills, minat kewirausahaan dan jiwa kewirausahaan sudah banyak dilakukan sebelumnya (Aprilianty, 2013; Rosmiati et al., 2015; Van Gelderen et al., 2008). Penelitian sbelumnya hanya membahas dua diantara tiga variabel yang diteliti, belum secara bersama sama. Selain itu, penelitian sebelumnya belum pernah dilakukan di lokasi yang berbeda. Penelitian ini bertujuan untuk mengetahui dan menganalisis pengaruh internalisasi soft skills dan minat kewirausahaan terhadap pembentukan jiwa kewirausahaan di MAN Se-Kabupaten Kuningan. Hasil penelitian ini diharapkan mampu menjadi informasi dan masukan bagi stakeholder terkait dalam pembentukan jiwa kewirausahaan siswa MAN Se-Kabupaten Kuningan.

\section{TINJAUAN PUSTAKA}

\section{Jiwa Kewirausahaan}

Jiwa kewirausahaan yaitu merupakan nyawa kehidupan dalam kewirausahaan yang pada dasarnya merupakan sikap dan perilaku kewirausahaan yang ditunjukkan melalui sifat, karakter, dan watak seseorang yang memiliki kemauan dalam mewujudkan gagasan inovatif ke dalam dunia nyata secara kreatif (Ang \& Hong, 2000). Selain itu, jiwa kewirausahaan dapat didefinisikan sebagai salah satu bekal untuk hidup dimasyarakat dengan baik. jiwa adalah sesuatu yang abstrak, yang dipelajari hanya pernyataan-pernyataan yang tampak dengan tubuh, atau gejala-gejala yang tampak sebagai gerak-gerik sehingga jiwa merupakan roh, setiap manusia mempunyai sifat dan gejala abstrak terjadi dari perasaan, pikiran, angan-angan dan sebagainya (Kirkwood, 2007).

Seseorang yang memiliki jiwa wirausaha adalah mereka yang didalam kepribadiannya telah terinternalisasikan nilai-nilai kewirausahaan, yakni kepribadian yang memiliki tindakan kreatif sebagai nilai, gemar berusaha, tegar dalam berbagai tantangan, percaya diri, memiliki self determination atau locus of control, berkemampuan mengelola risiko, perubahan dipandang sebagai peluang, toleransi terhadap banyaknya pilihan, inisiatif dan memiliki need for achievement, perfeksionis, perpandangan luas, menganggap waktu sangat berharga serta memiliki motivasi yang kuat, dan karakter itu semua telah menginternal sebagai nilai-nilai yang diyakini benar (Kuratko, 2003).

\section{Internalisasi Soft Skills}


Internalisasi menunjukan suatu proses dalam kaidah bahasa Indonesia akhiran-isasi mempunyai definisi proses. Sehingga internalisasi dapat didefinisikan suatu proses. Internasisasi dapat diartikan sebagai penghayatan, pendalaman, penguasaan secara mendalam yang berlangsung melalui binaan, bimbingan dan lainnya (Heckman \& Kautz, 2012). Soft skills adalah istilah sosiologis yang berkaitan dengan kecerdasan emosional, sifat kepribadian, ketrampilan sosial, komunikasi, berbahasa, kebiasaan pribadi, keramahan, dan optimisme yang mencirikan kemampuan seseorang dalam berhubungan dengan orang lain. Soft skill menyangkut karakter pribadi seseorang yang dapat meningkatkan interaksi individu, kinerja pekerjaan dan prospek karir (Weber, Finley, Carolina, \& Rivera, 2009).

Nilai-nilai kewirausahaan merupakan prasyarat yang berhubungan dengan perilaku kewirausahaan, (Morris \& Schindehutte, 2005) Nilai-nilai tersebut terdiri atas kreativitas, pengambilan risiko, inovasi, berorientasi prestasi, ambisi, dan kemerdekaan (Boohene, Sheridan, \& Kotey, 2008). Nilai dalam menjalankan bisnis mengandung unsur pertimbangan yang mengembangkan gagasan-gagasan seorang pribadi atau sosial, maka lebih dipilih dibanding dengan bentuk perilaku atau bentuk akhir keberadaan perlawanan atau kebaikan. Nilai menjadi dasar dalam memahami sikap dan motivasi serta nilai mampu mempengaruhi persepsi perilaku dalam menjalankan bisnis, oleh karena itu nilai sangat penting untuk dipelajari.

\section{Minat Kewirausahaan}

Minat adalah rasa lebih suka dan rasa keterikatan pada suatu hal aktivitas, tanpa ada yang menyuruh. Minat pada dasarnya adalah penerimaan akan suatu hubungan antara diri sendiri dengan sesuatu di luar diri (Flora Siagian, 2015). Berdasarkan kedua definisi di atas dapat ditarik kesimpulan bahwa minat adalah dorongan psikologis yang ditunjukkan oleh adanya kesadaran yang mendorong perhatian pada suatu obyek disertai keinginan untuk terlibat dengan obyek tersebut dalam usaha untuk memenuhi harapan-harapan yang telah ada dalam dirinya.

Minat kewirausahaan secara garis besar dipengaruhi oleh dua faktor yakni faktor internal dan faktor eksternal. Faktor internal adalah faktor yang timbul karena pengaruh dari dalam diri individu itu sendiri seperti kebutuhan akan pendapatan, harga diri, perasaan senang, dan lain-lain. Faktor eksternal adalah faktor yang mempengaruhi individu karena pengaruh dari luar dirinya sendiri yang meliputi lingkungan keluarga, lingkungan masyarakat, lingkungan internasional, perubahan teknologi, kondisi ekonomi, budaya dan sosial (Yoon, Tong, \& Loy, 2011).

\section{METODE}

Metode penelitian yang digunakan dalam penelitian ini adalah metode deskriptif verifikatif dengan alat bantu penyebaran kuesioner kepada siswa. Populasi penelitian ini adalah seluruh siswa MAN Se-Kabupaten Kuningan sebanyak 2.123. Berdasarkan perhitungan Slovin diperoleh sampel penelitian ini sebanyak 335 siswa dengan teknik pengambilan sampel proportional probality sampling. Berdasarkan jenis kelamin, siswa perempuan sebanyak 56\% dan siswa laki-laki sebanyak $44 \%$. Berdasarkan kelas, siswa kelas X sebanyak 25\%, siswa kelas XI sebanyak 35\% dan siswa kelas XII sebanyak $40 \%$. Berdasarkan asal sekolah, siswa MAN 1 Kuningan sebanyak 32\%, siswa MAN 2 Kuningan sebanyak 28\% dan siswa MAN 3 Kuningan sebanyak $40 \%$.

Pengukuran tingkat internalisasi soft skills indikatornya mengacu pada riset (Kuratko, 2003) yaitu kreativitas, pengambilan risiko, inovasi, berorientasi prestasi, ambisi dan kemerdekaan. Pengukuran tingkat minat kewirausahaan indikatornya mengacu pada riset (Rosmiati et al., 2015) yaitu perasaan senang, ketertarikan, perhatian dan keterlibatan. Pengukuran jiwa kewirausahaan indikator mengacu pada riset (Ningrum, 2017) yaitu percaya diri, penuh keyakinan, optimis, berkomitmen, disiplin, bertanggung jawab, cekatan dalam bertindak, memiliki jiwa kepemimpinan, tangguh dalam bertindak dan berani mengambil risiko. Pengumpulan data dilakukan menggunakan kuesioner kemudian dianalisis menggunakan statistik deskriptif dan statistika inferensial. Data yang 
telah terkumpul dianalisis dengan sistem skoring skala likert 5 poin dari sangat tidak setuju (1) hingga sangat setuju (5) untuk mendapatkan data interval dan diberi skor atau nilai. Instrumen penelitian diuji melalui uji validitas dan uji realibitas. Pengujian hipotesis dilakukan dengan regresi berganda.

\section{PEMBAHASAN}

\section{Gambaran Umum Internalisasi Soft Skills, Minat Berwirausaha dan Jiwa Kewirausahaan}

Berdasarkan perhitungan dan pengolahan data, dapat disusun distribusi frekuensi data internalisasi soft skill, Minat Berwirausaha dan Jiwa kewirausahaan seperti pada Table 1 dan Tabel 2 sebagai berikut:

Tabel 1.

Distribusi Frekuensi Variabel Internalisasi Soft Skills (X1), Minat Berwirausaha (X2) dan Jiwa Kewirausahaan (Y)

\begin{tabular}{|c|c|c|c|}
\hline No & Kelas Interval & Frekuensi & Persentase (\%) \\
\hline \multicolumn{4}{|c|}{ Variabel Internalisasi Soft Skills (X1) } \\
\hline 1 & $29-30$ & 21 & 6,27 \\
\hline 2 & $31-32$ & 30 & 8,95 \\
\hline 3 & $33-34$ & 35 & 10,45 \\
\hline 4 & $35-36$ & 71 & 21,19 \\
\hline 5 & $37-38$ & 98 & 29,25 \\
\hline 6 & $39-40$ & 90 & 26,86 \\
\hline & Jumlah & 335 & 100 \\
\hline \multicolumn{4}{|c|}{ Variabel Minat Berwirausaha (X2) } \\
\hline 1 & $29-30$ & 22 & 6,56 \\
\hline 2 & $31-32$ & 34 & 10,14 \\
\hline 3 & $33-34$ & 48 & 14,32 \\
\hline 4 & $35-36$ & 59 & 17,61 \\
\hline 5 & $37-38$ & 96 & 28,65 \\
\hline 6 & $39-40$ & 76 & 22,68 \\
\hline & Jumlah & 335 & 100 \\
\hline \multicolumn{4}{|c|}{ Variabel Jiwa Kewirausahaan (Y) } \\
\hline 1 & $29-30$ & 28 & 8,35 \\
\hline 2 & $31-32$ & 42 & 12,53 \\
\hline 3 & $33-34$ & 48 & 14,32 \\
\hline 4 & $35-36$ & 50 & 14,92 \\
\hline 5 & $37-38$ & 86 & 25,67 \\
\hline
\end{tabular}


6

\section{(2)}

$+2$

$39-40$

Jumlah
81

355
24,17

100

Sumber : Hasil Pengolahan Data, 2020

Berdasarkan Tabel 1 di atas untuk variabel internalisasi soft skills, dapat diketahui bahwa frekuensi terbanyak terdapat pada kelas interval 37-38 dengan jumlah frekuensi yaitu 98 responden $(29,25 \%)$ dan frekuensi terkecil terdapat pada kelas interval 29-30 dengan jumlah frekuensi yaitu 21 responden (6,27\%). Sedangkan untuk variabel minat berwirausaha, dapat diketahui bahwa frekuensi terbanyak terdapat pada kelas interval 37-38 dengan jumlah frekuensi yaitu 96 responden (28,65\%) dan frekuensi terkecil terdapat pada kelas interval 29-30 dengan jumlah frekuensi yaitu 22 responden (6,56\%). Selain itu, untuk variabel pembentukan jiwa kewirausahaan, dapat diketahui bahwa frekuensi terbanyak terdapat pada kelas interval 37-38 dengan jumlah frekuensi yaitu 86 responden $(25,67 \%)$ dan frekuensi terkecil terdapat pada kelas interval 29-30 dengan jumlah frekuensi yaitu 28 responden $(8,35 \%)$.

Tabel 2. Kategori Internalisasi Soft Skills (X1), Minat Berwirausaha (X2) dan Jiwa Kewirausahaan (Y)

\begin{tabular}{|c|c|c|c|c|}
\hline No & Kategori & Kelas Interval & Frekuensi & Persentase (\%) \\
\hline \multicolumn{5}{|c|}{ Variabel Internalisasi Soft Skills (X1) } \\
\hline 1 & Rendah & $29-32$ & 51 & 15,32 \\
\hline 2 & Sedang & $33-36$ & 106 & 31,64 \\
\hline 3 & Tinggi & $37-40$ & 188 & 56,12 \\
\hline \multicolumn{3}{|c|}{ Jumlah } & 335 & 100 \\
\hline \multicolumn{5}{|c|}{ Variabel Minat Berwirausaha (X1) } \\
\hline 1 & Rendah & 29-32 & 56 & 16,71 \\
\hline 2 & Sedang & 33-36 & 107 & 31,94 \\
\hline 3 & Tinggi & $37-40$ & 172 & 51,34 \\
\hline \multicolumn{3}{|c|}{ Jumlah } & 335 & 100 \\
\hline \multicolumn{5}{|c|}{ Variabel Jiwa Kewirausahaan (Y) } \\
\hline 1 & Rendah & $29-32$ & 70 & 20,89 \\
\hline 2 & Sedang & $33-36$ & 98 & 29,25 \\
\hline 3 & Tinggi & $37-40$ & 167 & 49,85 \\
\hline \multicolumn{3}{|c|}{ Jumlah } & 335 & 100 \\
\hline
\end{tabular}

Sumber : Hasil Pengolahan Data, 2020

Berdasarkan Tabel 2, untuk variabel internalisasi soft skills dapat diketahui bahwa internalisasi soft skills (X1) dari 355 responden dapat dikatakan bahwa kategori tinggi sebanyak 188 responden dengan persentase 56,12\%, kategori sedang sebanyak 106 responden dengan persentase 31,64\%, dan kategori rendah sebanyak 51 responden dengan persentase 15,32\%. Sehingga dapat dikatakan bahwa internalisasi soft skills siswa MAN Se-Kabupaten Kuningan tergolong tinggi yaitu ditunjukkan pada kelas interval 37-40 dengan persentase 56,12\% atau 188 responden dari jumlah total responden sebanyak 355. Sedangkan untuk variabel Minat Berwirausaha, dapat diketahui bahwa minat berwirausaha (X2) dari 355 responden dapat dikatakan bahwa kategori tinggi sebanyak 172 responden dengan persentase 51,34\%, kategori sedang sebanyak 107 responden dengan persentase $31,94 \%$, dan kategori rendah sebanyak 56 responden dengan persentase 16,71\%. Sehingga dapat dikatakan bahwa minat berwirausaha siswa MAN Se-Kabupaten Kuningan tergolong tinggi yaitu ditunjukkan pada kelas interval 37-40 dengan persentase 51,34\% atau 172 responden dari jumlah total responden sebanyak 355. Selain itu, untuk variabel jiwa kewirausahaan, dapat diketahui bahwa jiwa kewirausahaan (Y) dari 355 responden dapat dikatakan bahwa kategori tinggi sebanyak 167 
responden dengan persentase $49,85 \%$, kategori sedang sebanyak 98 responden dengan persentase $29,25 \%$, dan kategori rendah sebanyak 70 responden dengan persentase $20,89 \%$. Sehingga dapat dikatakan bahwa jiwa kewirausahaan siswa MAN Se-Kabupaten Kuningan tergolong tinggi yaitu ditunjukkan pada kelas interval 37-40 dengan persentase $49,85 \%$ atau 167 responden dari jumlah total responden sebanyak 355 .

\section{Pengaruh Internalisasi Soft Skill terhadap Jiwa Kewirausahaan}

Berdasarkan hasil pengolahan dan analisis data berpengaruh positif terhadap jiwa kewirausahaan siswa MAN Se-Kabupaten Kuningan. Temuan ini mendukung hasil temuan sebelumnya (Bygrave, 2010; Heckman \& Kautz, 2012; Weber et al., 2009) yang menyatakan internalisasi soft skills berpengaruh positif terhadap jiwa kewirausahaan. Soft-skills sendiri diartikan sebagai seluruh aspek dari generic skill yang juga termasuk elemen-elemen kognitif yang berhubungan dengan nonacademic skill. Internalisasi soft-skills dalam pembelajaran kewirausahaan dapat dilakuakan dengan berbagai cara diantaranya melakukan model terintegrasi yaitu menyatu dengan hard skill artinya melekat dan terpadu dengan program kurikuler, kurikulum yang ada atau dalam pembelajaran yang ada atau dalam proses pembelajaran dan yang kedua model komplementatif, implementasi soft-skill ditambahkan ke dalam program pendidikan kurikuler dan struktur kurikulum yang ada yang berkaitan dengan mata pelajaran kewirausahaan di sekolah. Hasil penelitian ini mengindikasikan bahwa apabila siswa ingin meningkatkan jiwa kewirausahaan, siswa dan sekolah harus menerapkan internalisasi soft skills dalam pembelajaran dan kehidupan sehari-hari.

\section{Pengaruh Minat Berwirausaha terhadap Jiwa Kewirausahaan}

Berdasarkan hasil pengolahan dan analisis data minat berwirausaha berpengaruh positif terhadap jiwa kewirausahaan siswa MAN Se-Kabupaten Kuningan. Temuan ini mendukung hasil penelitian sebelumnya (Bygrave, 2010; Ningrum, 2017) yang menyatakan minat berwirausaha berpengaruh positif terhadap jiwa kewirausahaan. Minat berwirausaha mengindikasikan kesukaan atau ketertarikan seorang untuk melakukan kegiatan berwirausaha. Minat berwirausaha tidak dibawa sejak lahir tetapi tumbuh dan berkembang melalui pendidikan dan pelatihan. Minat berwirausaha juga dapat dipengaruhi oleh adanya soft skills yang tinggi, karena menjadi wirausahawan dibutuhkan ketrampilan dan karakter diri yang kuat. Minat berwirausaha seseorang akan mempengaruhi jiwa berwirausaha karena jiwa kewirusahaan akan terbentuk dengan adanya ketertarikan terhadap dunia wirausaha. Hasil penelitian ini bahwa apabila ingin meningkatkan jiwa kewirausahaan siswa dapat dilakukan dengan cara menumbuhkan minat berwirausaha siswa terlebih dahulu.

\section{Pengaruh Internalisasi Soft Skills dan Minat Berwirausaha terhadap Jiwa Kewirausahaan}

Hasil penelitian menunjukkan adanya pengaruh internalisasi soft skills dan minat berwirausaha secara simultan terhadap jiwa kewirausahaan. Artinya semakin tinggi tingkat soft skills dan Minat berwirausaha seseorang maka semakin tinggi jiwa kewirausaha seseorang. Soft skills berkaitan dengan kecerdasan emosional, sifat kepribadian, ketrampilan sosial, komunikasi, berbahasa, kebiasaan pribadi, keramahan, dan optimisme yang mencirikan kemampuan seseorang dalam berhubungan dengan orang lain. Sedangkan minat berwirausaha rasa ketertarikan terhadap kegiatan berwirausaha yang menciptakan suatu usaha yang bermanfaat bagi diri sendiri dan lingkungan sekitar. Temuan ini mendukung hasil penelitian sebelumnya (Aprilianty, 2013; Flora Siagian, 2015; Kurniawan et al., 2016; Rosmiati et al., 2015) yang menyatakan bahwa internalisasi soft skills dan minat berwirausaha secara simultan terhadap jiwa kewirausaha.

\section{KESIMPULAN}


Berdasarkan hasil pengolahan dan pembahasan diatas, maka dapat ditarik kesimpulan bahwa tingkat jiwa kewirausahaan, internalisasi soft skill dan minat berwirausaha berada pada kategori tinggi. Hasil ini menunjukkan bahwa internalisasi soft skills dan minat berwirausaha memiliki pengaruh positif dan signifikan terhadap pembentukan jiwa kewirausahaan. Hasil ini menunjukkan bahwa tingkat internalisasi soft skills dan minat berwirausaha akan mempengaruhi pembentukan jiwa kewirausahaan siswa, sehingga internalisasi soft skill dan minat berwirausaha siswa harus ditingkatkan agar dapat membentuk jiwa kewirausahaan siswa baik ketika masih sekolah atau setalah lulus.

Berdasarkan hasil penelitian di atas penulis merekomendasikan 1) bagi siswa, untuk meningkatkan internalisasi soft skills dan minat berwirausaha dengan cara menambah pengetahuan dan keterampilan berwirausahan melalui pendidikan dan pelatihan-pelatihan kewirausahaan. 2) bagi pihak sekolah, terus menjalankan dan mendukung kurikulum pendidikan kewirausahan di sekolah dengan baik serta memberikan ruang yang cukup bagi siswa yang memiliki minat dan jiwa menjadi seorang wirausaha.

\section{DAFTAR PUSTAKA}

Ang, S. H., \& Hong, D. G. P. (2000). Entrepreneurial spirit among East Asian Chinese. Thunderbird International Business Review, 42(3), 285-309. https://doi.org/10.1002/15206874(200005/06)42:3<285::aid-tie2>3.0.co;2-5.

Aprilianty, E. (2013). Pengaruh kepribadian wirausaha, pengetahuan kewirausahaan, dan lingkungan terhadap minat berwirausaha siswa SMK. Jurnal Pendidikan Vokasi, 2(3), 311-324. https://doi.org/10.21831/jpv.v2i3.1039.

Bhasin, B. B., \& Venkataramany, S. (2010). Globalization Of Entrepreneurship : Policy Considerations For SME. 9(4), 95-104.

Boohene, R., Sheridan, A., \& Kotey, B. (2008). Gender, personal values, strategies and small business

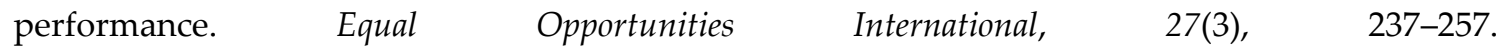
https://doi.org/10.1108/02610150810860075.

Buchholz, R. A., \& Rosenthal, S. B. (2005). The spirit of entrepreneurship and the qualities of moral decision making: Toward a unifying framework. Journal of Business Ethics, 60(3), 307-315. https://doi.org/10.1007/s10551-005-0137-0.

Bygrave. (2010). Kontribusi Soft Skill Dalam Menumbuhkan Jiwa Kewirausahaan. Jurnal Ilmiah Among Makarti, 3(5), 95-104. Retrieved from http://jurnal.stieama.ac.id/index.php/ama/article/view/20/18.

Fikroh, S., Lestari, K. T., \& Tuban, P. R. (n.d.). KECAMATAN SEMANDING KABUPATEN TUBAN. 193-195.

Fletcher, T. D., \& Nusbaum, D. N. (2010). Development of the Competitive Work Environment Scale: A Multidimensional Climate Construct. Educational and Psychological Measurement, 70(1), 105124. https://doi.org/10.1177/0013164409344492.

Flora Siagian, R. E. (2015). Pengaruh Minat dan Kebiasaan Belajar Siswa terhadap Prestasi Belajar Matematika. Formatif: Jurnal Ilmiah Pendidikan MIPA, 2(2), 122-131. https://doi.org/10.30998/formatif.v2i2.93.

Ghosh, P., \& Cheruvalath, R. (2007). Indian Female Entrepreneurs as Catalysts for Economic Growth and Development. The International Journal of Entrepreneurship and Innovation, 8(2), 139-147. https://doi.org/10.5367/000000007780808048. 
Heckman, J. J., \& Kautz, T. (2012). Hard evidence on soft skills. Labour Economics, 19(4), 451-464. https://doi.org/10.1016/j.labeco.2012.05.014.

Kadiyono, A. L. (2014). Efektivitas Pengembangan Potensi Diri Dan Orientasi Wirausaha Dalam Meningkatkan Sikap Wirausaha. Jurnal Intervensi Psikologi (JIP), 6(1), 25-38. https://doi.org/10.20885/intervensipsikologi.vol6.iss1.art2.

Kirkwood, J. (2007). Igniting the entrepreneurial spirit : is the role parents play gendered ? 13(1), 39-59. https://doi.org/10.1108/13552550710725174

Kuratko, D. F. (2003). Entrepreneurship Education: Emerging Trends and Challenges for the 21 St Century. Unm.Edu, 124-136. Retrieved from http://www.unm.edu/ asalazar/Kauffman/Entrep_research/e_ed.pdf.

Kurniawan, A., Khafid, M., \& Pujiati, A. (2016). Pengaruh Lingkungan Keluarga, Motivasi, dan Kepribadian Terhadap Minat Wirausaha Melalui Self Efficacy. Journal of Economic Education, 5(1), 100-109.

Morris, M., \& Schindehutte, M. (2005). Entrepreneurial values and the ethnic enterprise: An examination of six subcultures. Journal of Small Business Management, 43(4), 453-479. https://doi.org/10.1111/j.1540-627X.2005.00147.x.

Ningrum, M. A. (2017). Peran Keluarga dalam Menumbuhkan Jiwa Wirausaha Sejak Usia Dini. Jurnal Pendidikan (Teori Dan Praktik), 2(1), 39. https://doi.org/10.26740/jp.v2n1.p39-43.

Nursiah, T., Kusnadi, N., \& Burhanuddin, B. (2017). Perilaku Kewirausahaan pada Usaha Mikro Kecil (UMK) Tempe di Bogor Jawa Barat. Jurnal Agribisnis Indonesia, 3(2), 145. https://doi.org/10.29244/jai.2015.3.2.145-158

Priyono, A. H. (2017). MENINGKATKAN KOMPETENSI TENAGA KERJA INDONESIA YANG BEKERJA KE LUAR NEGERI ( Studi Pada Kantor Cabang PT. Berkat Sukses Makmur Sejahtera). 33(1), 43-51.

Rosmiati, R., Junias, D. T. S., \& Munawar, M. (2015). Sikap, Motivasi, Dan Minat Berwirausaha Mahasiswa. Jurnal Manajemen Dan Kewirausahaan (Journal of Management and Entrepreneurship), 17(1), 21-30. https://doi.org/10.9744/jmk.17.1.21-30.

Van Gelderen, M., Brand, M., Van Praag, M., Bodewes, W., Poutsma, E., \& Van Gils, A. (2008). Explaining entrepreneurial intentions by means of the theory of planned behaviour. Career Development International, 13(6), 538-559. https://doi.org/10.1108/13620430810901688.

Weber, M. R., Finley, D. A., Carolina, N., \& Rivera, D. (2009). An exploratory study identifying soft skill competencies in entry-level managers. Tourism and Hospitality Research, 9(4), 353-361. https://doi.org/10.1057/thr.2009.22.

Yoon, D., Tong, K., \& Loy, L. C. (2011). Factors Influencing Entrepreneurial Intention Among University Students. International Journal of Social Sciences and Humanity Studies, 3(1), 487-496. 